is also an advantage in not having the rope too limp, because it will glide more readily between the uterus and growth if it be moderately stiff. These qualities, with great tenacity, the annealed steel wire-rope possesses to a great degree, provided the annealing be not carried too far so as to make the wire rotten. The above points have been carefully gone into by Mr. Durroch, of St. Thomas's-street; and with his instruments it has fortunately happened that we have never been troubled by breakages.

That the chain ecraseur is the more powerful instrument I do not dispute; but for obstetric purposes there is no difficulty in making the wire-rope strong enough, with sufficient cutting powers, provided the above points are attendei to ; and by its flexibility it is evident that it possesses a power of adaptation impossible in the chain.

I should not have ventured to occupy your valuable space had I not been anxious to explain the uses of an instrument which I feel will be found the most generally useful of any yet in our hands. - I am, Sir, yours obediently,

J. Braxton Hrcks, M.D.

St. Thomas's-street, S.E., Nov. 12th, 1864.

M R. ERASM U S W L S O N. To the Editor of THE LANCET.

SrR, - In your journal of this date, a correspondent, "A micus," addresses to me three questions, which, with your permission, I will endeavour to answer, and with as much brevity as possible.

The first question requires that I should state in what man ner I became connected with St. John's Hospital. It was thus :About six montha ago Dr. Tilbury Fox and Dr. Frodsham ap plied to me to co operate with them in the "foundation of a clinical hospital for diseases of the skin." I agreed to do so; and those gentlemen exerted themselves with great assiduity in searching for a house adapted for our purpose. They found several, but there was always some insurmountable obstacle to stop our progress just as we fancied that we had succeeded in our object. After various fruitless attempts, we became aware that Mr. Milton had established a hospital for diseases of the skin in Westminster, under the name of St. John's Hospital and Mr. Milton, having heard of our intentions, came to me and offered to place his hospital at our disposal. We felt grateful to him for his liberal offer, and accepted it willingly.

I will now address myself to the second question, which is thus worded: "explain his association with the London Journal as medical editor, in which capacity he gave gratuitous advice on diseases of the skin in the columns of that periodical to any person who addressed him." About four or five years ago, my friend Mr. Mark Lemon wrote to me to say that he had becoms the proprietor of the London Joumal, and invited my co-operation to give it popularity by writing some articles on the Physiology of the Skin. I assented, and six or seven such papers were published. One afternoon, while in the editor's room, that gentleman called my aitention to a number of letters from correspondents, containing queries on all sub jects, and some on medicine; and, as I knew how incorrectly and imperfectly answers to these questions were generally given, I offered to reply to them. It was my intention to do so anonymously; but, to my mortification, the very next journal that appeared made the announcement that medical questions would be answered by me. I need hardly say that this un authorized announcement was not repeated; and it resulted in my declining to continue my self-imposed duty, which I had andertaken only as an experiment, and with the hope of doin good. A few weeks later the journal passed into other hands, and my interest in and connexion with it ceased. This state ment scarcely justifies my being called the "medical editor" of the journal. And in my mode of answering the queries I endeavoured to keep within such honourable limits as I believed might be permitted to the scholar and the gentleman.

The third remark of your correspondent is to the effect that "the friends of Mr. Erasmus Wilson have also regretted to observe his name on the labels of certain vendors of hairwashes and pomades." I hardly know how to reply to this. I brlieve it to be a fact that there is not a chemist or druggist in the Onited Kingdom who will not hand to anyone who asks for it a hair-lotion bearing my name; pomade I know nothing about excepting some cantharadine pomades made many years ago by Messrs. Savory and Moore at my suggestion. But the chemists and druggists have obtained the formulæ of this and other lotions from my published works or from my prescrip tions; and, however much I may join in the regret of my friends at the use thus made of my name, I see no means of escaping it. It has happened to others as well as myself, and we see daily the names of eminent men associated with popular remedies of varions kinds prepared from their prescriptions. I can only say that I have not encouraged this practice in my own instance.

In conclusion, Sir, permit me to say that nothing would give me more pain than the feeling that I had deserved the censure of TuE LANCET. The founder of that journal was my earliest and always most kind friend, and on all occasions most ready to give me a helping hand in the furtherance of my views while the aims of THE LANCET in the advocacy of the best in terests of the profession have always been as sincere as they have been powerfu?.

I remain, Sir, your obedient serrant,

Henrietta-streft, Cavendish-square, Erasmus Wilson. Nov, 12th, 1864 .

\section{CONDITION OF THE HEART IN EMPHYSEMA OF THE LUNGS.}

\section{To the Eatitor of THE LANCET.}

SIR, - With all due respect for Dr. Waters, of Liverpool, he appears to $m e$, in his paper on the above subject which is pub. lished in THe Lancer of Nov, 12th, to attempt to explain a well.known fact in physiology in a way which is unnecessary, as the usual and simpler explanation is quite sufficient for the purpose; and, as it seems to me, the farfetched one of Dr Waters is anatomically unsound. On the geveral subject of the effect of emphysema of the lungs on the heart I join issue with him, but to his explanation of the cause of the hypertrophy of the left ventricle in this disease I beg to take excep. tion. His proposition, as I understand it, is, that though the impediment on the right side of the heart to the onward flow of the blood to the lungs, from their altered structnre, is sufficient to account for the hypertrophy of the right side of the heart, "no such explanation as that just given will apply to the hypertrophy of the left ventricle." Now I maintain that the very same explanation which is sufficient for the right side, is also sufficient for the left; the only dufference beingand which Dr. Waters alludes to in his second paragraph-that it takes longer time to effect the change: i. e., the emphysema must have continued during a greater period, as it will first, no doubt, affect the right side of the heart; but if the cause is prolonged, the effect will be propagated backwards along the course of the blood current, and will in time have the same effect on the left ventricle as it had previously on the right ventricle.

Dr. Waters goes on to explain that the hypertrophy of the lefo side is caused by the displacement of the heart, which no doubt alters the relation of the axis of the chambers of the heart to that of the great vessels, and thereby, Dr. Waters affirms, causes the impediment to the flow of the blood from the left ventricle into the aorta. Now the anatomy of the heart teaches us that, so far from the change of position of the heart towards the mesial line being likely to increase the difference of direction of the axis of the left ventricle and that of the aorta, it has the contrary effect, causing them to incline more towards a right line. The direction of the ascending aorta being upwards, forwards, and to the right, it is evident that the tilting of the heart towards the anterior mediastinum must have the effect of partially removing the natural curve of the aorta-certainly not of increasing it. I think, therefore, wo had better fall back on the more reasonable explanation (which in truth is only cause and effect), that any obstacle to the onward flow of the blood is directly propagated backwards; and it is only a question of time as to when the retarding influence shall be felt at the head of the stream.

I am, Sir, your obedient servant,

City-road, Manchester, Nov. 1864. JoHN HUMTER, M.A.

\section{THE BRITISH MEDICAL ASSOCIATION AND} ITS WEEKLY PRINT.

\section{To the Eaitor of THE LANCET.}

SrR,-I have been so fortunate as to draw from the editor of the British Mcdical Journal a highly important admission, which is worthy of a wider publicity than it can obtain in his own pages. I wrote to him last week to inquire whether be 